\title{
Surface Roughness Influence on CPE Parameters in Electrolytic Cells
}

\author{
Denner S. Vieira ${ }^{1}$, Paulo R. G. Fernandes ${ }^{1,2}$, Hatsumi Mukai ${ }^{1,2}$, Rafael S. Zola ${ }^{1,3}$, Giane Gonçalves \\ Lenzi $i^{*}$, Ervin K. Lenzi ${ }^{5}$ \\ ${ }^{1}$ Departamento de Física, Universidade Estadual de Maringá, Avenida Colombo, 5790 - 87020 - 900 \\ Maringá - PR, Brazil \\ ${ }^{2}$ National Institute of Science and Technology for Complex Fluids, CNPq, 05508 - 090 São Paulo - SP \\ ${ }^{3}$ Departamento de Física, Universidade Tecnológica Federal do Paraná, R. Marcílio Dias, 635 - 86812 \\ - 460 Apucarana - PR, Brazil \\ ${ }^{4}$ Departamento de Engenharia Química, Universidade Tecnológica Federal do Paraná, Av Monteiro \\ Lobato, 84016-210 - Ponta Grossa - PR - Brasil \\ ${ }^{5}$ Departamento de Física, Universidade Estadual de Ponta Grossa, Av. General Carlos Cavalcanti 4748 \\ - 84030 - 900 Ponta Grossa - PR, Brazil \\ *E-mail: gianeg@utfpr.edu.br
}

doi: $10.20964 / 2016.09 .56$

Received: 1 June 2016 / Accepted: 18 July 2016 / Published: 7 August 2016

We investigate how the changes on the electrode surface may influence the behavior of the constantphase elements (CPE) and, consequently, electrical response of an electrolytic cell. This analysis is performed by using an experiment with Milli-Q water and stainless steel electrodes with three different types of polishment: smooth, fine sandpaper, and rough sandpaper. The experimental data is obtained from an Electrical Impedance Spectroscopy (EIS) measure and analyzed by means of an equivalent circuit with CPE elements.

Keywords: Electrical Impedance, CPE, Surface roughness, PNP

\section{FULL TEXT}

(C) 2016 The Authors. Published by ESG (www.electrochemsci.org). This article is an open access article distributed under the terms and conditions of the Creative Commons Attribution license (http://creativecommons.org/licenses/by/4.0/). 